Research Article

\title{
Protection Effect of Self-Nanoemulsifying Drug Delivery System (SNEDDS) Piroxicam as Ulcerogenic Agent towards Malondialdehid Level and Protein Expression of Caspase-3, COX-1, COX-2 at Rat Gastric
}

\author{
Iis Wahyuningsih ${ }^{1}$, Kurnia Ambarwati ${ }^{1}$, Erninda Ayu Hapsari ${ }^{1}$, Afifah Fauziyyah ${ }^{1}$, Azis Ikhsanudin ${ }^{1}$, Deasy \\ Vanda Pertiwi ${ }^{1}$, Wahyu Widyaningsih ${ }^{1 *}$ \\ ${ }^{1}$ Faculty of Pharmacy, Universitas Ahmad Dahlan, Yogyakarta 55164 Indonesia \\ *Corresponding author: Wahyu Widyaningsih I Email: widyaningsihwahyu@yahoo.com
}

Received: 19 September 2020; Revised: 19 October 2020; Accepted: 26 October 2020; Published: 26 October 2020

\begin{abstract}
Piroxicam can damage the gastric mucosa through two main mechanisms, topical and systemic. Topical mucosal damage occurs because the piroxicam is lipophilic and acidic, making it easier for hydrogen ions to enter the mucosa and cause ulcers. The aim of this study was to determine the protection effect of SNEDDS piroxicam ulcerogenic agent against malondialdehyde (MDA) level and protein expression of caspase3, COX-1, COX-2. The research was conducted using the test animals as much as 30 male white Sprague dawley (SD) rats aged 1-2 months with a weight of 100-200 grams divided into 5 groups consisting of Normal Control, Trigger Control, Drug Control, Carrier Control and Treatment Control. Treatment was given for 28 days orally. On the 29th day blood samples were also taken for the determination of MDA (Malondialdehid) levels by Thiobarbituric Acid Reactive Substance (TBARs) method using a visible spectrophotometer. Rats were sacrificed, then gastric organs were taken for immunohistochemical testing of caspase-3 and COX-1 expression, COX-2. The statistical analysis showed that the piroxicam SNEDDS group and the piroxicam suspension group decreased expression of the caspase-3 protein, increased COX-1 expression, decreased COX-2 and significantly decreased MDA levels. The piroxicam-containing SNEDDS (Self-Nanoemulsifying Drug Delivery System) form has protection effect against ulcogenic piroxicam by decreasing the caspase-3, MDA and COX-2 levels.
\end{abstract}

Keywords : ulcerogenic; caspase-3; COX-1; COX-2; MDA; piroxicam; SNEDDS

\section{INTRODUCTION}

Non-steroidal anti-inflammatory drugs (NSAIDS) are the most commonly used drugs for analgesics, antipyretics, and anti-inflammatory drugs. One of the commonly used NSAIDs is piroxicam [1]. Piroxicam is one of the NSAID-class drugs that can cause side effects in the digestive tract of gastric ulcers. One of the causes of gastric ulcers is the long-term use of non-steroidal antiinflammatory drugs (NSAIDs) [2]. The incidence of peptic ulcers in Indonesia due to the use of nonsteroidal anti-inflammatory drugs (NSAIDs) amounted to $46 \%$ of a total of 4 million patients [3].

Piroxicam can damage the gastric mucosa through two main mechanisms, topical and systemic. Topical mucosal damage occurs because the piroxicam is lipophilic and acidic, making it easier for hydrogen ions to enter the mucosa and cause ulcers. This cell damage is caused by oxidative stess that causes increased reactive oxygen species (ROS). In the body, ROS can cause lipid peroxidation process [4]. Lipid peroxidation is oxidative destruction of long-chain unsaturated fatty 
acids that produce malondialdehyde compounds (MDA). Thus, MDA can be used as an index of measurement of free radical activity in the body. High levels of MDA in the body can be caused by increased free radical activity.

The systemic effects of NSAIDs through inhibition of cyclooxygenase (COX) enzymes play a role in converting arachidonic acid to prostaglandins, prostacyclines and thromboxane. COX has 2 forms, that is, COX-1 plays a role in the formation of prostaglandins that function to maintain normal tissue, whereas COX-2 may arise from inflammation [5,6].

Gastric damage due to the use of NSAIDs occurs due to defense physicochemical defects and systemic inhibition of gastric mucosal protectors through cell death called gastric apoptosis [7]. Caspase- 3 expression is one of the markers for apoptotic activity because caspase- 3 is one of the proapoptotic agents that acts as the main effector caspase (executor) in the apoptotic process [8].

Piroxicam belongs to the second classes Biopharmaceutical Drug Classification System, with low solubility and high permeability leading to low, irregular and low-impact drug absorption [911]. In addition, acidic piroxicam can erode and irritate the stomach [12].

One alternative is to increase the dissolution of piroxicam with the formation of the Self nanoemulsifying drug delivery system (SNEDDS), a technology of lipid-based drug delivery systems that increase the oral bioavailability of lipophilic drugs [13]. Nanoemulsions are mixtures or water and stabilized surfactants by surfactants with particle sizes between $20-200 \mathrm{~nm}$ which can protect drug particles insoluble in gastric fluid so as not to come into contact with the gastric mucosa [14,15]. This method can replace the role of prostaglandin as cytoprotective thereby decreasing the resulting ulcerogenic effect [16]. The results of Wulandari (2017) SNEDDS formula can decrease the ulcerogenic effect of piroxicam [17]. This study aims to examine the effect of ulcerogenic protection of SNEDDS Piroxicam on MDA levels, COX-1 expression, COX-2 and caspase-3 expression on Rat's stomach.

\section{MATERIALS AND METHODS}

\subsection{Materials}

The materials used in this study were piroxicam which was obtained from PT. Indofarma, Tbk; tween 80 obtained from Bratachem; PEG 400 obtained from Bratachem; VCO from CV. Cipta Kimia; polyvinylpirolidone (PVP) were obtained from CV. Cipta Kimia; ketamine $1 \% ; 0.9 \% \mathrm{NaCl}$ and distilled water; $10 \%$ technical formaldehyde obtained from the Integrated Testing and Research Laboratory Unit IV Gadjah Mada University.

\subsection{Preparation of SNEDDS piroxicam}

Mixed $0.6 \mathrm{ml} \mathrm{VCO}$ with $1.2 \mathrm{ml}$ PEG 400 and $3.2 \mathrm{ml}$ tween 80 . Then performed vortex for 5 minutes and disonikasi at $45^{\circ} \mathrm{C}$ for 5 minutes. After that $50 \mathrm{mg}$ of pyrolysamic powder was added every $5 \mathrm{ml}$. Vortex performed again for 5 minutes and disonikasi at $45^{\circ} \mathrm{C}$ for 5 minutes. Repeated the vortex process above, with sonication for 10 minutes. Then all the process is repeated 2 times. [18].

\subsection{Characteristics test of SNEDDS piroxicam}

The SNEDDS piroxicam characteristic test was performed with three tests, namely: SNEDDS clarity test performed by looking at the transmittance percent value, physical stability test performed by testing the effect of $\mathrm{pH}$ and temperature, and the effect of temperature changes; and emulsification time test by calculating SNEDDS piroxicam time can be optimally emulsified in aquades medium. 


\subsection{Treatment of animals}

Male Sprague Dawley rats aged 1-2 months were used in this study. The animals were housed in air conditioned room and were kept in standard laboratory condition, which included a 12-h light-dark cycle and temperature $(25 \pm 2)^{\circ} \mathrm{C}$. The rats were fed with standard pellet diet AD-2 (Comfeed Industries Ltd) and water ad libitum. All procedures related with animal experiments were approved by the Animal Ethical Committee of Universitas Ahmad Dahlan (No. 011702020).

\subsection{Ulcerogenic effect test of SNEDDS piroxicam on rat}

The ulcerogenic SNEDDS piroxicam effect test was performed using the hull of the Sprague dawley (SD) strain rat. In this study, 30 test animals were divided into 5 groups consisting of Normal Control, Trigger Control, Drug Control, Carrier Control and Treatment Control. In the normal control group only was given aquades, 1\% PVP for suspending control, pyroxicam suspension was administered for the drug control group, SNEDDS base for carrier control and SNEDDS piroxicam for the treatment control group. Treatment was done orally for 28 days. Then on the 29 th day mice and blood surgery were performed on the eye orbital sinus for the determination of MDA levels. The gastric organs were taken for immunohistochemical testing to see the expression of caspase-3, COX1 and COX-2.

\subsection{Preparation of histopathology examination}

After stomach was taken the gastric tissue was immersed in $0.9 \%$ physiological $\mathrm{NaCl}$ solution for the next 15 minutes. The gastric tissue was fixed in a 10\% buffered Neutral Formalin (BNF) solution for 24 hours with organ ratio and 1:10 solution and then dehydrated in a multilevel ethanolic solution, ie $70 \%, 80 \%, 90 \%, 100 \%, 100 \%$, and 100\% respectively for 1 hour at room temperature. After clearing using xylol 3 times for 15 minutes at room temperature then the tissue was infiltrated into the xylol mixture and liquid paraffin for 15 minutes then the tissue was infiltrated back into liquid paraffin 3x for 60 minutes each. If the tissue is embedded into liquid paraffin and cooled to room temperature to form paraffin blocks then the formed paraffin blocks are cut using microtom in a horizontal direction with a thickness of $3-4 \mu \mathrm{m}$ then the piece is placed over the waterbath at a temperature of $460 \mathrm{C}$ until the paraffin block is lost.

\subsection{Immunohistochemical discharge of caspase-3, COX-1, and COX-2 proteins}

The process of painting immunohistochemical caspase-3, COX-1, and COX-2 is done by deparafinization process ie preparations included in staining jar. The tissue soaked in xylene for 20 minutes was then put in absolute ethanol for 10 minutes. Then put in $90 \%$ ethanol, $80 \% 70 \%$ for each sequence for 1 minute. Blocking peroxidase was performed by preparing soaked with $0.3 \% \mathrm{H} 2 \mathrm{O} 2$ for 15 minutes. Then washed with aquadest and tris buffer in sequence for $2 \times 5$ minutes. Retrival antigen is carried out by heating in citric buffer for $4 \times 5$ minutes, after which it is cooled to room temperature and then washed with tris buffer for $3 \times 5$ minutes. Blocking non-specific bindings is done with the preparations dripped with Ultra V Block for 10 minutes. Preparations are dropped with anti-caspase3 primary antibodies in PBS A (1: 200) for 10 minutes. Next washed with tris buffer as much as 3x5 minutes then spilled with Bioatynilated link antibody for 10 minutes and washed with tris buffer for 2x5 minutes. The preparations were then sterilized with Streptavidin Peroxidase for 10 minutes and washed with tris buffer for $2 \times 5$ minutes. Preparations are sterilized with Diamino Benzidine (DAB) chromogen ( 1 in 50 parts of substrate) for 15 minutes. Then washed with aquadest. Then do the 
counterstain with ditematesi Hematoxylin Meyers for 1 minute, then washed with running water. The dehydration was carried out by preparation immersed in 50\%, 60\%,70\%, 80\%, 90\%, and 50\% respective absolutes respectively for 1 minute, then immersed in xylene I, II, III for 3 minutes each. The next step of mounting is done by preparing it with a canada balsame, then covered with a glass desk [19].

\subsection{Determination of MDA content}

The determination of the activity of MDA level was conducted at Biochemistry Laboratory of Faculty of Medicine, Gadjah Mada University. In determining the activity of MDA content of specimen used was serum rats. MDA measurement method used in this research is Thiobarbituric acid reactive substance (TBARs) method. The reagents used are TBA reagents and larval extraction of butanol. Preparation of TBA reagents was prepared by $40.5 \mathrm{~mL}$ ( $20 \%$ acetic acid in buffer to $\mathrm{pH} 3.5$ with $1 \mathrm{~N} \mathrm{NaOH}$ ), $13.2 \mathrm{~mL}$ SDS $8.2 \%, 40.5 \mathrm{~mL}$ (TBA $0.8 \%$ in bidest), then mixed all three and added with bidest to $100 \mathrm{~mL}$. Furthermore, the making of butanol extraction solution is by comparison of $\mathrm{N}$-butanol, bidest, pyridine (15:3: $1 \mathrm{v} / \mathrm{v}$ ) material. The determination procedure was: $1 \mathrm{~mL}$ of sample plus $4 \mathrm{~mL}$ of TBA reagent, then divortex, then incubated with waterbath at $90^{\circ} \mathrm{C}$ for $80 \mathrm{~min}$, after which cooled cold water (ice) approximately $10 \mathrm{~min}$, after cold, added $4 \mathrm{~mL}$ extract solution butanol, then divortex and centrifuged $3000 \mathrm{rpm}$ for 20 minutes. The top layer is taken and read at $532 \mathrm{~nm}$, $532 \mathrm{~nm}$, and $560 \mathrm{~nm}$ wavelengths using a visible spectrophotometer. The standard solution used is 1,1,3,3-tetramethoxypropane (TMP) [24].

\subsection{Data analysis}

Data on MDA levels $(\mu \mathrm{mol} / \mathrm{L})$ were statistically analyzed with $95 \%$ significancy level. Data levels were tested for normality using the Kolmogrov-Smirnov test to determine whether the data was normally distributed or not. Followed by the homogeneity test, namely the Levene test to determine the homogeneity of the data. If the data obtained were normally distributed and homogeneous ( $p>0.05$ ), a One way ANOVA test was performed, followed by the Post hoc LSD test to compare between treatment groups. However, if the data were not normally distributed and or unhomogeneous $(\mathrm{p}<0.05)$ then the Kruskal-wallis test was continued, then continued with the MannWhittney test to compare between treatment groups.

\section{RESULTS AND DISCUSSION}

\subsection{Characteristics of SNEDDS piroxicam}

The resulting SNEDDS piroxicam character has met the clarity and emulsification time. Clarity is expressed in percent transmittance. Measurement of the transmittance percent is done to prove that the emulsion droplet has reached the nanometer size of less than $100 \mathrm{~nm}$. The measurements were performed using UV-Vis spectrophotometry at a wavelength of $650 \mathrm{~nm}$ with aqua-dio blanks [20]. The results show that the average transmittance value of three replications is $99.38 \% \pm 0.23$. This value is close to $100 \%$, so it can be stated that the emulsion droplet in SNEDDS piroxicam formula has reached the nanometer size [21]. The size of the dispersed phase greatly affects the appearance of the emulsion. When the nanoemulsion formed is passed through the light, the light beam is transmitted, resulting in a large transmittance value [22]. 
The emulsification time is the time it takes for the system to form a homogeneous mixture in a medium with light stirring. This character describes the time it takes SNEDDS to form an emulsion in the gastrointestinal tract. SNEDDS should be able to form spontaneous nanometer-sized emulsions in the gastrointestinal tract with mild agitation such as peristalsis. SNEDDS is said to be good when the emulsification time is produced in less than a minute with a clear and transparent appearance [13]. The results showed that the emulsification time of SNEDDS piroxicam was able to fully emulsified to form nanoemulsion in less than a minute ie 38.97 seconds \pm 7.14 . When the emulsion is formed there is interaction between tween 80 and PEG 400. PEG 400 as kosurfaktan can increase fluidity through penetration and form empty space between surfactant molecules, so PEG 400 plays a role in accelerating emulsification time [23].

\subsection{MDA level, COX-1, COX-2 and caspase-3 expressions}

Table 1. The Malondialdehid (MDA) activity of mice on the 29th day

\begin{tabular}{lcccc}
\hline Group(s) & $\begin{array}{c}\text { MDA Level } \\
(\mu \mathrm{mol} / \mathrm{L})\end{array}$ & $\begin{array}{c}\text { COX-1 } \\
\text { Expression }\end{array}$ & $\begin{array}{c}\text { COX-2 } \\
\text { Expression }\end{array}$ & $\begin{array}{c}\text { Caspase-3 } \\
\text { Expression }\end{array}$ \\
\cline { 2 - 4 } & \multicolumn{4}{c}{ Mean \pm SD } \\
\hline Aquadest & $2.2980 \pm 0.52026$ & $6.32 \pm 1.47$ & $10.02 \pm 1.97$ & $13.90 \% \pm 6.21$ \\
PVP 1\% & $4.2360 \pm 0.92360$ & $36.31 \pm 5.70$ & $39.82 \pm 4.87$ & $9.9 \% \pm 14.28$ \\
Piroxicam & $6.2160 \pm 0.88889$ & $26.09 \pm 4.25$ & $72.05 \pm 5.29$ & $56.07 \% \pm 25.97$ \\
suspension & & & & \\
SNEDDS Carrier & $3.0400 \pm 0.31121$ & $71.68 \pm 6.14$ & $43.37 \pm 4.15$ & $25.78 \% \pm 12.41$ \\
SNEDDS Piroxicam & $3.9380 \pm 0.51853^{*}$ & $28.29 \pm 7.75^{*}$ & $22.70 \pm 3.83^{*}$ & $4.55 \% \pm 4.01^{*}$ \\
\hline
\end{tabular}

Note :

All variables are shown as Mean \pm SD for $n=5 .{ }^{*} p<0.05$ compared with the piroxicam suspension control

Different signification results were shown in the piroxicam suspension group with the SNEDDS group. The value of significance shows significantly different results with $p<0.05$ which is 0.023 which means that SNEDDS and piroxicam group have different effect that SNEDDS have less effect of ulserogenik. The decrease of ulcerogenic effect of SNEDDS piroxicam is also seen in the \% of protection produced by $57.89 \%$, so it can be concluded that the effect of ulcerogenic due to piroxicam drug can be derived with SNEDDS piroxicam formula.

The increased levels of MDA indicate that the lipid peroxidation process causes damage to gastric mucosal cells [25]. This is in accordance with Wulandari's research which states that piroxicam suspension at a dose of $5.04 \mathrm{mg} / \mathrm{kgBW}$ for 14 days can cause ulcerogenic effects with an ulcer index of 3.8. This value is higher than the control ulcer value of control suspension which is 0.4 [26].

Figure C (Fig. 1) is the piroxicam suspension group, the resulting image shows the number of brown cells. These results suggest that many cells in this group are apoptotic. Figure D is the base group SNEDDS, in this group also found some brown cells, meaning in this group still occur caspase3 expression but in normal scale. These results indicate that the ingredients of SNEDDS do not induce the occurrence of stomach cell damage, thus proving safe to use. 
3.3. Caspase-3 expression
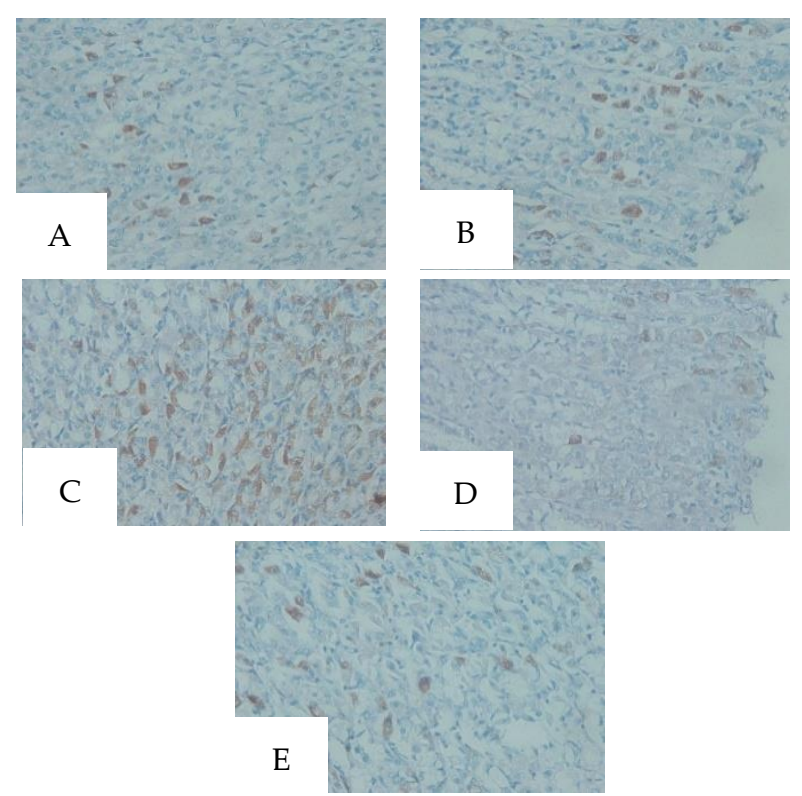

Figure 1. The results of the caspase- 3 test on the gastric tissues of five test groups. $A=$ aquades; $B=P V P 1 \% ; C$ = piroxicam suspension; $\mathrm{D}=$ SNEDDS carrier; $\mathrm{E}=$ SNEDDS piroxicam

Figure $\mathrm{E}$ is the piroxicam SNEDDS group, the results obtained show images with some cells expressing caspase-3 because they are brown. However, when compared with caspase-3 expression in Figure C (group of suspense piroxicam), the figure E (SNEDDS piroxicam group) is much less. This suggests that the manufacture of SNEDDS piroxicam is indeed capable of being an anti apoptotic agent.

The brown color of the cells occurs due to the $\mathrm{DAB}$ stain which reacts with the peroxidase enzyme from hydrogen peroxidase to give a dark brown color. DAB acts as a substrate which is a benzidine diamino, which is a chromogen that can produce a color precipitate called chromoganin. $\mathrm{DAB}$ is commonly used in peroxidase reactions. This compound can detect the presence of peroxidase, so that it is visualized by a brown deposit [27].

Peroxidase enzymes will catalyze or accelerate chromogen to visualize color in specific cells that produce certain antibodies. These primary antibodies are polyclonal antibodies, namely anti caspase- 3 and secondary antibodies are antibodies that have been conjugated with the peroxidase enzyme. In the immunohistochemical test (Fig. 1), the expression of caspase-3 in the gastric tissue in five test groups can be seen. This is in accordance with previous research which states that the biggest side effect of continuous use of piroxicam is peptic ulcers [28].

Figure C (Fig.2) is the piroxicam suspension group, the resulting image shows the number of brown cells. These results suggest that many cells in this group are apoptotic. Figure $\mathrm{D}$ is the base group SNEDDS, in this group also found some brown cells, meaning that in this group still occur expression of COX-1 but in normal scale. These results indicate that the ingredients of SNEDDS do not induce the occurrence of stomach cell damage, thus proving safe to use. 


\subsection{COX-1 Expression}

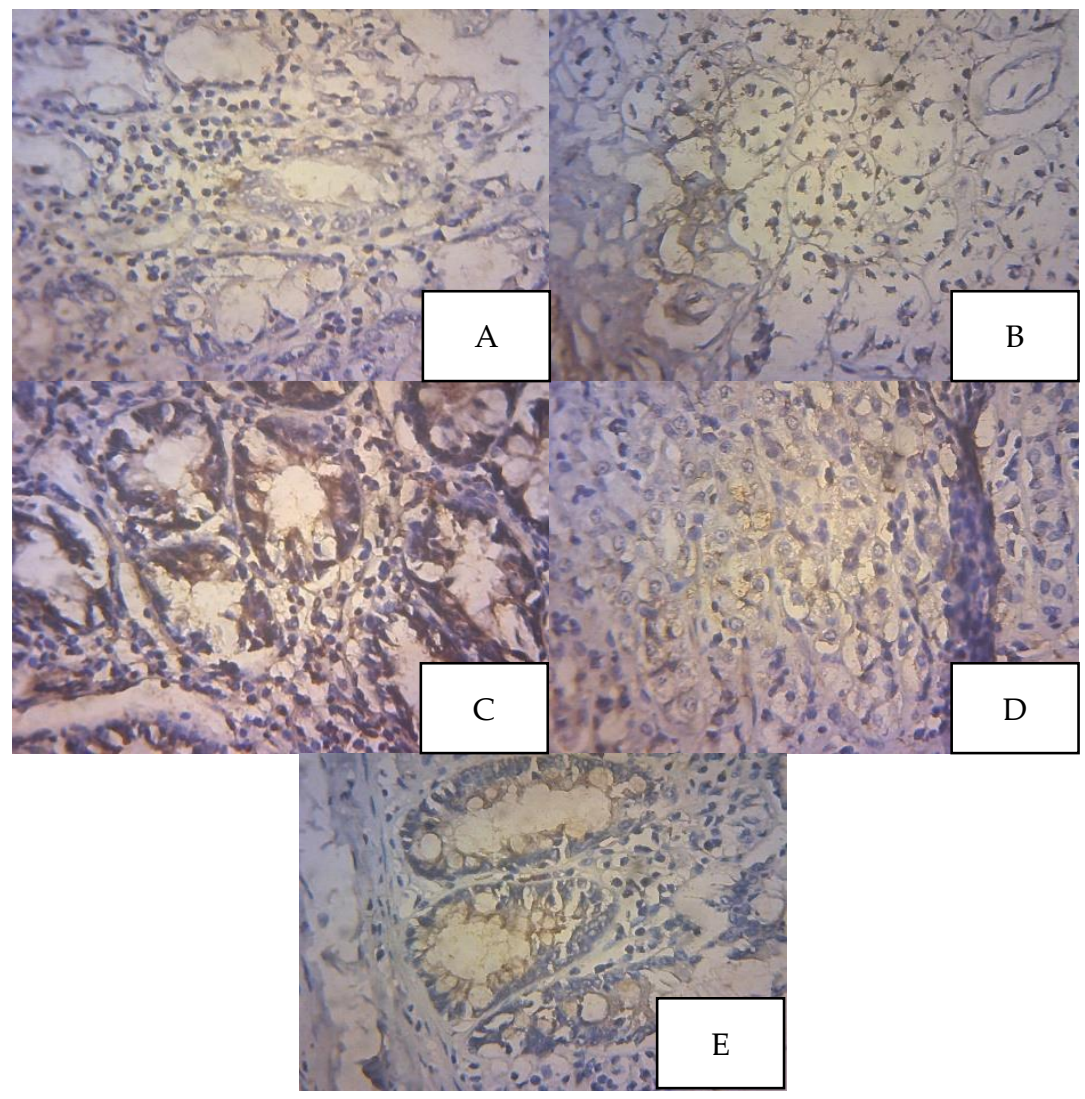

Figure 2. The results of the COX-1 test on the gastric tissue of five test groups

Figure $\mathrm{E}$ is a piroxicam SNEDDS group, the results obtained show an image with some COX1-expressing cells because they are brown. However, when compared with the expression of COX-1 in Figure C (piroxicam suspension group), the figure E (SNEDDS piroxicam group) does not contain brown cells. This suggests that the manufacture of SNEDDS piroxicam is indeed capable of being an anti apoptotic agent.

Figure C (Fig. 3) is the piroxicam suspension group, the resulting image shows the number of brown cells. These results suggest that many cells in this group are apoptotic. Figure $\mathrm{D}$ is the base group SNEDDS, in this group also found some brown cells, meaning that in this group still occur expression of COX-2 but in normal scale. These results indicate that the ingredients of SNEDDS do not induce the occurrence of stomach cell damage, thus proving safe to use.

Figure $\mathrm{E}$ is a piroxicam SNEDDS group, the results obtained show an image with some COX2 expressing cells because they are brown. However, when compared with the expression of COX-2 in Figure C (piroxicam suspension group), the figure E (SNEDDS piroxicam group) does not contain brown cells. This suggests that the manufacture of SNEDDS piroxicam is indeed capable of being an anti apoptotic agent.

The results showed that piroxicam SNEDDS was able to reduce the expression of COX-2 protein. This is in accordance with the theory because COX-2 protein is a protein identified as an inflammatory mediator protein. The decrease in COX-2 expression will decrease the ulcerogenic effect of piroxicam, presumably due to the effect of modification of the piroxicam drug delivery system in line with the previous research [29]. 


\subsection{COX-2 Expression}

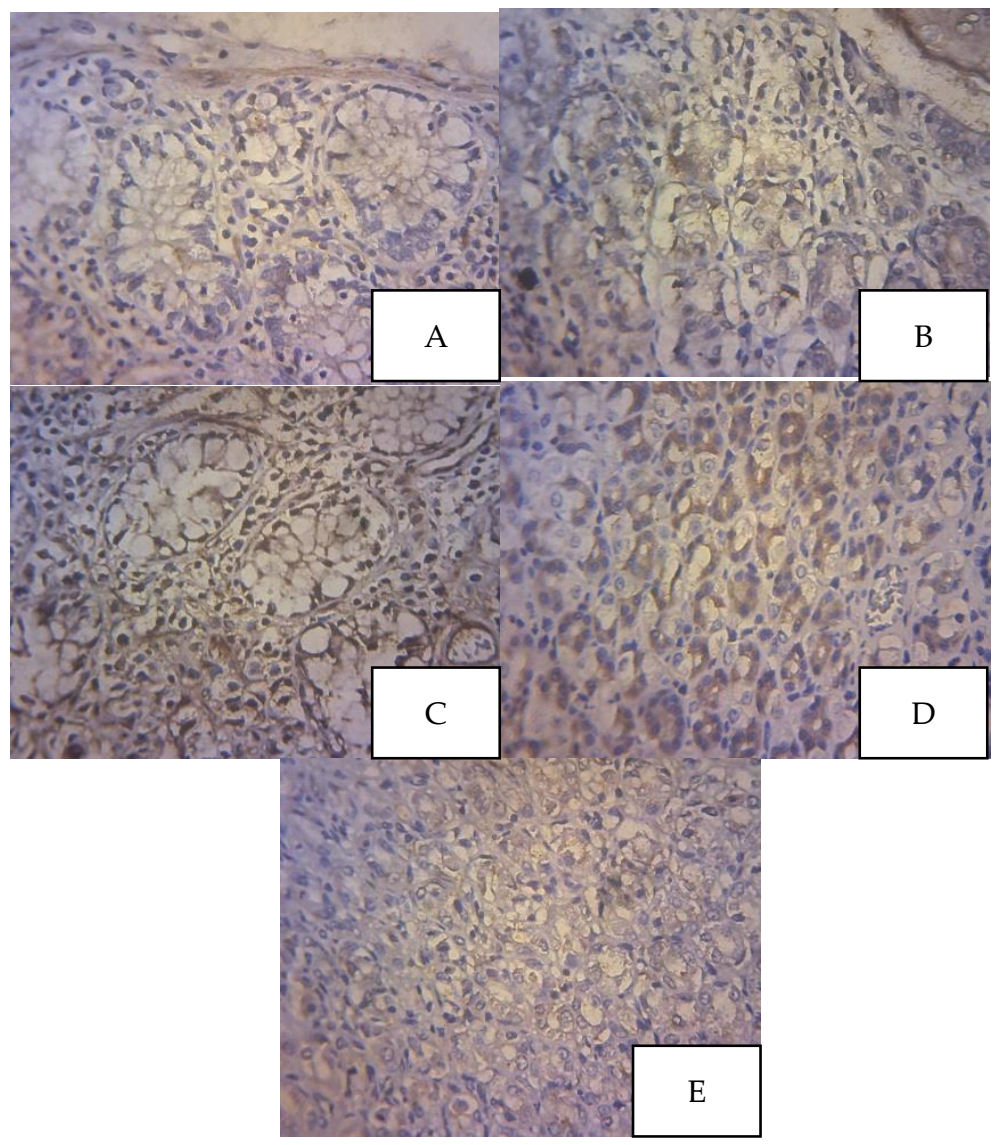

Figure 3. Immunohistochemical painting results with 400 times magnification of COX-2 protein with the group: (a) Normal group (b) Suspension group (c) Piroxicam suspension group 10.8 $\mathrm{mg} / \mathrm{KgBB}$ (d) base group SNEDDS (e) SNEDDS piroxicam group

Notes : $\longrightarrow$ Unexpressed cells $\longrightarrow$ Cells that are expressed

The releasing mechanism of piroxicam from SNEDDS is influenced by the partition between the oil phase (VCO) and the external water medium. Degradation of the oil phase (VCO) in an external water medium is thought to trigger drug release, osmotic swelling occurs which leads to piroixicam emulsion breakdown (SNEDDS) and leads to drug release. According to previous research, drug release or drug release from SNEDDS can occur in 2 ways, by transfer and carrier degradation. The mechanism for releasing SNEDDS piroxicam by a nanoemulsion that is formed will protect the particles from piroxicam that are insoluble in gastric liquids, so that the piroxicam particles do not directly meet the gastric mucosa [30]. By this protection, it can replace the role of prostaglandins as cytoprotective, so that the ulcerogenic effect can be reduced.

In addition, nanoemulsion droplets $(<100 \mathrm{~nm})$ that have been formed will increase the interface area of the oil with gastrointestinal fluids which contain various enzymes which will increase the solubility of piroxicam in gastrointestinal stain, so that the dissolution of the piroxicam drug will increase and reduce insoluble piroxicam particles. In the stomach, it can be concluded that the possible ulcerogenic effects will be reduced [31,32]. 


\section{CONCLUSION}

Based on the results of this study, it can be concluded that the Self-Nanoemulsifying Drug Delivery System (SNEDDS) piroxicam can decrease MDA level, expression of caspase-3, COX-1 and COX-2 proteins in gastric cells of sprague dawley rats.

Funding : This research was funded by KEMENRISTEK DIKTI Republik Indonesia, grant No. PF052/SP3/LPP-UAD/IV/2017.

Acknowledgement : The authors extend their appreciation to KEMENRISTEK DIKTI Republik Indonesia for financial support through college grant No. PF-052/SP3/LPP-UAD/IV/2017.

Conflict of Interest : No conflict of interest associated with this work.

\section{Reference}

1. Sigit JI, Ribkah and Andreanus AS. Efektivitas Preventif Omeprazol terhadap Efek Samping Tukak Lambung Antiinflamasi Nonsteroid (Asetosal) pada Tikus Galur Wistar Betina. Acta Pharmaceutica Indonesia. 2012, 37(2): 48-53.

2. Rani A, Marcellus S, and Ari FS. Buku Ajar Gastroenterologi (Edisi I). Interna Publishing, Jakarta, 2011.

3. Bukhari MH, Khalil J, Qamar S, Qamar S, Qamar Z, Zahid M, Ansari N, and Bakhshi IM. Comparative Gastroprotective effects of natural honey, Nigella sativa and cimetidine against acetylsalicylic acid induced gastric ulcer in albino rats. Journal of the College of Physicians and Surgeons Pakistan. 2011, 21(3): 151-156.

4. Halliwel B and Gutteridge JMC. Free Radical in Biology and Medicine ( $3^{\text {th }}$ edition). Oxford University Press, New York, 2000.

5. Bjarnason I. Gastrointestinal Safety of NSAIDs and Over the Counter Analgetics. The Internasional Journal of Clinical Practice. 2012, 178: 37-42.

6. Luigi M, Pilar GI, and Xavier C. Management of NSAID Associated Peptic Ulcer Disease. Expert Review of Gastroenterology and Hepatology. 2016.

7. Scheiman JM. Nonsteroidal Antiinflamatory Drug (NSAID)-Induced Gastropathy. Dalam: KimK, editor, Acute Gastrointestinal Bleeding; Diagnosis and Treatment. Humana, New Jersey, 2006, pp7593.

8. Krajewska M, Wang HG and Krajewski S. Immunohistochemical Analysis of In Vivo Patterns of Expression of CPP32 (Caspase 3), A Cell Death Protease., Journal of Cancer Research. 2007, 57: 16051613.

9. $\mathrm{Wu} \mathrm{CY}$ and Benet LZ. Predicting Drug Disposition via Application of BCs: Transport/Absorption/Elimination Interplay and Development of Biopharmaceutics Drug Disposition Classification System. Pharmaceutical Research. 2005, 22(1): 11-23.

10. Blagden N, De Matas M, Gavan PT and York P. Crystal Engineering of Pharmaceutical Ingredient to Improve Solubility and Dissoltion Rates. Elsevier. 2007, 59: 617-630.

11. Brayfield AM. The Complete Drug Reference. The Pharmaceutical Press, Lambert High Street, London SEI 7JN, United Kingdom, 2014, pp125-127.

12. Corwinn EJ. Handbook of Pathophysiology (3rd Edition). The Ohio State University, Columbus, 2008. 
13. Balakumar K, Raghavan CV, Selvan NT, Prasad RH and Abdu S. Self-Nano Emulsifying Drug Delivery System (SNEDDS) of Rosuvastatin Calsium: Design, Formulation, Bioavailability and Pharmacokinetic Evaluation. Colloids and Surfaces Biointerfaces. 2013, 112: 337-343.

14. Anuradha S, Patel PA and Hedge D. Peppermint Oil based Drug Delivery System of Aceclofenac with Improve Anti Inflammatory Activity and Reduced Ulcerogenecity. International Journal of Pharma Bioscience and Technology. 2013, 1: 89-101.

15. Chen H, Khemtong C, Yang X, Chang X and Gao J. Nanonization Strategies for Poorly Water Soluble Drugs. Drug Discovery Today. 2011, 16(7-8): 354-360.

16. Neal MJ. At a Glance Farmakologi Medis (Edisi 5). Penerjemah Surapsi J. Erlangga Medical Series, Jakarta, 2006.

17. Wulandari S. Pengaruh Pemberian Self-Nano Emulsifying Drug Delivery System (SNEDDS) Piroksikam terhadap Efek Ulserogenik Piroksikam pada Tikus Putih Jantan Galur Wistar. (Skripsi). Fakultas Farmasi, Universitas Ahmad Dahlan, Yogyakarta, 2017.

18. Dewi EC. Pengembangan Self-Nano Emulsifying Drug Delivery System (SNEDDS) Piroksikam menggunakan Fase Minyak VCO. Skripsi. Fakultas Farmasi, Universitas Ahmad Dahlan, Yogyakarta, 2016.

19. Solmi R, Lauriola M, Francesconi M, Martini D, Voltattorni M, Ceccareli C, Ugolini G, Rosati G, Zanotti S, Montroni I, et al. Displayed Correlation Between Gene Expression Profiles and Submicroscopic Alterations in Response to Cetuximab, Gefitinib and EGF in Human Colon Cancer Cell Lines. BMC Cancer. 2008, 8: 227

20. Lalwani G, Henslee AM, Farshid B, Lin L, Kasper FK, Qin YX, Mikos AG and Sitharaman B. TwoDimensional Nanostructure Reinforced Biodegradable Polymeric Nanocomposites for Bone Tissue Engineering. Biomacromolecules. 2013, 14(3): 900-909

21. Bali V, Ali M and Ali J. Study of Surfactant Combinations and Development of a Novel Nanoemulsion for Minimising Variations in Bioavailability of Ezetimibe. Colloids and Surfaces Biointerfaces. 2010, 76: 410-420

22. Sahumena MH. Pengembangan Nanopartikel Ketoprofen dengan teknik SNEDDS dan Uji Aktivitas Antiinflamasi. (Thesis). Universitas Gadjah Mada, Yogyakarta, 2014.

23. Belhadj Z, Zhang S, Zhang W and Wang J. Formulation Development and Bioavailability Evaluation of Self Nanoemulsifying Drug Delivery System (SNEDDS) of Atorvastatin Calsium. International Journal of Pharmaceutics. 2013, 29(1): 1103-1113.

24. Phyles, LA, E.J, and Einzig, S. Spectrophotometric Measurement of Plasma 2-Thiobarbituric Acid Reactive Substance in Presencs of Hemoglobin and Bilirubin Interference. Proc. Soc. Exp. Biol. Med, 1993, 20:407-419.

25. Sahu, C. R. Mechanisms Involved in Toxicity of Liver Caused by Piroxicam in Mice and Protective Effects of Leaf Extract of Hibiscus rosa-sinensis L., Libertas Academica, 2016, 9: 9-13.

26. Wulandari, S. Pengaruh Pemberian Self-Nano Emulsifying Drug Delivery System (SNEDDS) Piroksikam terhadap Efek Ulserogenik Piroksikam pada Tikus Putih Jantan Galur Wistar, (Skripsi), Fakultas Farmasi Universitas Ahmad Dahlan, Yogyakarta, 2017.

27. Samson, E., and Unitly, A.J.A. Ekspresi Immunoglobulin A (Ig A) pada Usus Halus Tikus Putih (Rattus norvegicus), Basic Science, 2014, 385-391. 
28. Scarpignato, C. Piroxicam- $\beta$-Cyclodextrin: A GI Safer Piroxicam. Current Medicinal Chemistry, 2013, 20: $2415-2437$.

29. Dkhil, M., Othman, DM., Al-Quraishy, S., Moneim, AEA. Olive (Olea europaea) leaf methanolic extract prevents $\mathrm{HCl} /$ ethanol induced gastritis in rats by attenuating inflammation and augmenting antioxidant enzyme activities. Biomedicine \& Pharmacotherapy, 2017, 91.

30. Anuradha, S.P., Patel, P.A., and Hegde, D. Peppermint Oil Based Drug Delivery System of Aceclofenac with Improve Anti Inflammatory Activity and Reduced Ulcerogenecity, International Journal of Pharma Bioscience and Technology, 2013, 1(2): 89-101.

31. Makadia, A.H., Bhatt, A.Y., Parmar, R.B., Paun, J.S., and Tank, H.M. Self Nanoemulsifying Drug Delivery System (SNEDDS): Future Aspect, Asian J. Pharm, 2013, 3(1): 22.

32. Mahmoud, H., Al-Suwayeh, S., and Elkadi, S. Design and Optimization of Self Nanoemulsifying Drug Delivery Systems of Simvastatin Aiming Dissolution Enhancement, African Journal of Pharmacy and Pharmacology, 2013, 7(22): 1482-1500.

(C) 2020 by the authors. Submitted for possible open access publication under the terms and conditions of the Creative Commons Attribution (CC BY) license (http://creativecommons.org/licenses/by/4.0/). 